\title{
LITHUANIAN AND LATVIAN SOCIAL EDUCATORS' OCCUPATIONAL STRESS AND THE ANALYSIS OF ITS COPING POSSIBILITIES: SOCIAL EDUCATORS' EXPERIENCES
}

\author{
Rita Orska \\ Rezekne Academy of Technologies, Latvia \\ Daiva Alifanovienè \\ Odeta Šapelytė \\ Siauliai University, Lithuania
}

\begin{abstract}
Stress is a condition related to complaints or disturbances of physical, psychological or social nature, which occur, if an individual does not feel able to fulfil all the requirements and expectations. In order to cope with stress situations, a person makes a particular effort for the regulation of it, in other words, for coping (overcoming, self-control). The coping is a multidimensional construct. The studies on this construct are rather recent in science, are carried out in the last twenty years. Due to that, the focus in stress research has shifted. Currently, more studies are conducted on prevention problems, how to develop and find resources in personality to cope with stress effectively. The first results of the study on the stress management peculiarities of social educators are reviewed in this paper as well. The research aim: to disclose the context of manifestation of occupational stress experienced by Lithuanian and Latvian social educators and its coping possibilities.
\end{abstract}

Keywords: social educator, social workers, stress, stress management, stress coping strategies, coping possibilities.

\section{Introduction}

Stress and psychosocial risks at work are one of the main work safety and healthcare problems in Europe. They affect significantly both person's health and the economic welfare of organizations and countries.

Stress has a negative impact on organizations in various ways, for instance, reduction of business efficiency, increase in absenteeism, increase in a number of employees, who come to work while being ill and unable to perform their duties, as well as increase in a number of accidents and injuries. There are several causes of stress, for instance, content of work, organization, environment, and poor communication at work. 
While performing social work to help a client in his life situation, the work of social specialist should be oriented towards the "change" of client's relationships with the environment and other people, not towards the "change" of the client himself. Relationship development in social work is the most essential, in order to help the client efficiently, ascertain his needs and resources, so the client can solve his situation on his own. The quality of relationships and the pace of consultation process is affected by both the client's and social worker's personality, character traits, personal life experience, culture, values, traditions and internal motivation. In many cases, it is complicated to help the client to solve the situation; there are no desired results for a long term, often the client gives up due to difficulties. It causes stress for both the social worker and the client.

If a person feels stressed for a longer period of time and he has no possibility or skills to affect it (i.e. chronic stress), it requires considerable resources from a person, mobilization, and, as a result, person's psychological and physical sense of self is affected. Chronic stress results in a number of psychological and somatic symptoms, for instance, a sense of helplessness, depression, anxiety, inability to see perspective; deterioration of social relationships, working capacity, personal performance, and cognitive abilities take place, behavioural disorders, sleep disorders, health problems (for instance, gastric and cardiac disorders, headache) and other expressions occur. These symptoms do not necessarily mean illness, but, if a person cannot regulate stress, they can result in serious psychological and physical illnesses.

Therefore, stress management issue is very important. R. Lazarus and S. Folkman set two types of stress management: problem-oriented stress management, in which the progress is focused towards the resolution of stress situation, and emotion-oriented management, which is applied in situations that cannot be changed.

The research aim: to disclose the context of manifestation of occupational stress experienced by Lithuanian and Latvian social educators and its coping possibilities.

The research subject: the context of manifestation of occupational stress experienced by Lithuanian and Latvian social educators and its coping possibilities.

\section{Theoretical aspects of stress management}

H. Selye, the founder of the stress theory, consideres that stress is a nonspecific response of the body to any demand of the body (Selje, 2011). T. Cox, in his turn, defines stress as any effect that disrupts the natural balance of the body. Changes in the body include both physical injuries, different types of illnesses and emotional disorders (Cox, 1985). Yet, there is an opinion that stress arises only 
with the circumstances that are difficult to overcome for the body (Cuyne \& Lazarus, 1980).

K. Maslach (Maslach, 1982) believes that "professional burnout" is related to the mismatch between work and personality. If this mismatch becomes too strong, burnout risk increases. Six mismatch types are proposed:

- between work and worker's resources. The requirements set for a worker are much higher than he actually can fulfil. Social work is related to a considerable mental effort, processing of complex information. Social workers must take full responsibility for the effective resolution of the client's problems and meeting the social needs every day.

- $\quad$ between the desire for independence at work and strict management control. Any expression of independence or creativity is suppressed; workers must comply with the management regulations.

- between a personality and his work assessment (wage). Undervaluation of one's own work, considering it insignificant, as well as underestimation of oneself as a professional occurs. Social welfare workers' work assessment is insufficient. Social work weaknesses are topicalized in the media more frequently than the positive results.

- $\quad$ between a personality and his relationships with the other colleagues. More frequently, it is related to the lack of social support and the assessment (positive) of work from colleagues. In rural communities, a social worker is most often the only specialist in his field.

- between a personality and sense of justice. Most frequently, it is related to the labour payment and resources invested in the work (energy, time). Social welfare workers' work assessment is insufficient in comparison with input into the fulfilment of work tasks.

- $\quad$ between ethical moral personality principles and work requirements. Most frequently, it is related to the mismatch between morally ethical and religious beliefs and work specificity. For instance, workers must provide people with information, in which they do not believe themselves, or even intentionally mislead people.

After the review of psychological factors of social welfare workers' work, it is obvious that there is a possibility of distress risk and, over a longer period of time, the risk of burnout syndrome development. The research carried out in 2011 by B. Mikelsone "The causes of professional stress and the peculiarities of the situational anxiety level of social workers and employees of non-governmental organizations" shows that the average rates of anxiety in subject groups, according to the Spielberg anxiety questionnaire, correspond to a medium high situational 
anxiety level. Major stress causes are relationships with others, career and achievements, work strain (Mikelsone, 2011).

Every person tries to do something to overcome stress. Overcoming comprises cognitive, emotional and behavioural strategies. There is a wide range of stress overcoming strategies, the systematization and description of strategies is provided in a number of papers, but there is no common classification. Stress overcoming strategies in psychology literature are called coping strategies.

R. Lazarus sets out two types of strategies, which differ in terms of focus on strain:

- problem-focused strategy, oriented towards the resolution of the problem caused by the stressor;

- $\quad$ emotion-focused strategy, oriented towards work with emotions - to change the perception of a subjective situation in a way that the imbalance of demands and resources would not cause stress (Bartlett, 1998; Lazarus \& Folkman, 1984).

In problem-focused stress coping, a person is aware of all the information on possible measures and mobilizes for a certain action with an aim to change the threatening situation to a safe and harmless one. These actions could be directed towards oneself and the environment, using both aggression, rationality and responsibility (Vazne, 2011).

Emotion-focused stress coping regulates emotions that are caused by a stress situation. A person can avoid thinking about the situation and also overrate it, without changing the real situation itself. Reassessment of stress is very important in the situations when reality is unchangeable. Emotion-focused stress coping includes distancing, self-control, search for social support, escape, avoidance, responsibility and positive overvaluation (Vazne, 2011).

According to the views of various authors, stress situations can be solved effectively, using several strategies simultaneously and working practically. Avoidance, escape and the strategy of positive overvaluation of the situation are considered ineffective.

\section{The research sample and methodology}

The respondents $(\mathrm{N}=33)$ - social educators in Lithuania and Latvia - were chosen from educational institutions employing the purposive convenience sampling method. The professionals' experience was analyzed using the qualitative data collection method (semi-structured interview), which employed open-ended questions that did not limit possible answers according to assessment areas foreseen by the researchers. The latter were distinguished conducting the analysis of the scientific literature and authors' studies disclosing peculiarities of stress experienced by adults representing different development periods, 
professions and activity areas (Bubelienè \& Merkys, 2009 ,2012; Frydenberg \& Lewis, 1993; Folkman \& Maskovič, 2004; Valickas, Grakauskas, \& Želvienė, 2010; Kepalaite 2013; Kriukova, 2010; Lazarus \& Folkman, 1984).

The content of answers, which constituted the basis of the study, was broken down by corresponding diagnostic areas, subdivided into categories (diagnostic indicators), notional statements were selected. Rating of each category was identified by calculating the frequency of notional statements of the category. In the course of the research, the specialists' subjective experience about stress experienced in the professional activity, its coping techniques, strategies had to disclose. Research data were handled applying the content analysis method, using an open coding procedure (Corbin \& Strauss, 2014).

\section{Analysis of Research Results}

The study aimed to analyze what ways and strategies were used by social educators in order to cope with or reduce stress in their professional activity. We present the data (Table 1), analysing subjective experiences of these professionals.

Table 1 Ways of Coping with Occupational Stress Used by Lithuanian and Latvian Social

\begin{tabular}{|c|c|c|c|c|}
\hline Category & Sub-category & Proving statement & $\begin{array}{l}\text { No. of } \\
\text { state- } \\
\text { ments } \\
\text { LT }\end{array}$ & $\begin{array}{l}\text { No. of } \\
\text { state- } \\
\text { ments } \\
\text { LV }\end{array}$ \\
\hline \multirow{6}{*}{$\begin{array}{l}\text { Dissociation } \\
\text { from a } \\
\text { stressful } \\
\text { situation }\end{array}$} & $\begin{array}{l}\text { Activities } \\
\text { helping to } \\
\text { relax }\end{array}$ & $\begin{array}{l}\text { "a walk"; "I breathe in fresh air"; "I } \\
\text { drink a cup of coffee, tea to relax"; } \\
\text { "sitting near the fire" }\end{array}$ & 17 & 4 \\
\hline & $\begin{array}{l}\text { Purposeful } \\
\text { leisure }\end{array}$ & $\begin{array}{l}\text { "reading books"; "crafts"; "watching } \\
\text { comedies"; "music"; "crosswords" }\end{array}$ & 10 & 17 \\
\hline & $\begin{array}{l}\text { Physical } \\
\text { activity, sport }\end{array}$ & $\begin{array}{l}\text { "physical work", "sport", "active stay } \\
\text { in the nature" }\end{array}$ & 6 & 13 \\
\hline & $\begin{array}{l}\text { Separation of } \\
\text { professional } \\
\text { and personal } \\
\text { relationships } \\
\end{array}$ & $\begin{array}{l}\text { "I try not to bring bad memories about } \\
\text { work home, I try to dissociate"; "I tried } \\
\text { to solve everything at work"; "I don't } \\
\text { work at the weekends" }\end{array}$ & 6 & 10 \\
\hline & $\begin{array}{l}\text { Diversion of } \\
\text { emotions and } \\
\text { self-control }\end{array}$ & $\begin{array}{l}\text { "I tried to forget everything quickly and } \\
\text { engage in other activities",; "I learned } \\
\text { to control myself"; " I try to react } \\
\text { calmly, not to raise my voice, to calm the } \\
\text { child or family members" }\end{array}$ & 4 & 6 \\
\hline & $\begin{array}{l}\text { Avoidance and } \\
\text { retreat }\end{array}$ & $\begin{array}{l}\text { "I try to avoid stress"; "if possible, I } \\
\text { avoid" }\end{array}$ & 2 & 2 \\
\hline
\end{tabular}


Rita Orska, Daiva Alifanovienè, Odeta Šapelytè. Lithuanian and Latvian Social Educators' Occupational Stress and the Analysis of its Coping Possibilities: Social Educators' Experiences

\begin{tabular}{|c|c|c|c|c|}
\hline \multirow[t]{7}{*}{$\begin{array}{l}\text { Solution of } \\
\text { problems }\end{array}$} & $\begin{array}{l}\text { Discussion of } \\
\text { the situation } \\
\text { with the staff }\end{array}$ & $\begin{array}{l}\text { "I discuss with colleagues"; "we have } \\
\text { a discussion of the situation", "we find } \\
\text { new ways of solutions", "we try to look } \\
\text { at the situation in a new way or another } \\
\text { aspect"; "we analyze complex } \\
\text { situations"; "self-help groups," }\end{array}$ & 15 & 12 \\
\hline & $\begin{array}{l}\text { Professional } \\
\text { development }\end{array}$ & $\begin{array}{l}\text { "I was looking for ways how to } \\
\text { overcome this"; "I was reading } \\
\text { literature on the subject"; "we } \\
\text { addressed for help to other institutions, } \\
\text { professionals" }\end{array}$ & 8 & 12 \\
\hline & $\begin{array}{l}\text { Development } \\
\text { of a positive } \\
\text { attitude }\end{array}$ & $\begin{array}{l}\text { "I look at the situations positively: the } \\
\text { glass is not half empty but half full", "I } \\
\text { am learning to enjoy things" }\end{array}$ & 7 & 4 \\
\hline & $\begin{array}{l}\text { Distinguishing } \\
\text { of priorities at } \\
\text { work }\end{array}$ & $\begin{array}{l}\text { "I am trying to select the most } \\
\text { important works", "I choose important } \\
\text { works for learners rather than for } \\
\text { inspectors",; "I plan works and } \\
\text { prioritise"; "I select what is most } \\
\text { important every day and what allows to } \\
\text { perform tasks well" }\end{array}$ & 6 & - \\
\hline & $\begin{array}{l}\text { Coping with } \\
\text { stress on one's } \\
\text { own }\end{array}$ & $\begin{array}{l}\text { "I try to solve problems on myown", "I } \\
\text { persuade myself", "I tried to } \\
\text { concentrate and solve" }\end{array}$ & 5 & - \\
\hline & $\begin{array}{l}\text { Discussion of } \\
\text { the } \\
\text { circumstances } \\
\text { of the situation } \\
\text { with the } \\
\text { pupil's family }\end{array}$ & $\begin{array}{l}\text { "I talked to the children's mother"; "I } \\
\text { explained to the family"; "I first sorted } \\
\text { out with the family" }\end{array}$ & 5 & - \\
\hline & $\begin{array}{l}\text { The talk with } \\
\text { the pupil }\end{array}$ & $\begin{array}{l}\text { "I talk with teens"; "I succeed to } \\
\text { convince" }\end{array}$ & 5 & - \\
\hline \multirow[t]{2}{*}{\begin{tabular}{|l|} 
Social \\
support
\end{tabular}} & $\begin{array}{l}\text { Colleagues' } \\
\text { support }\end{array}$ & $\begin{array}{l}\text { "I received support, understanding, } \\
\text { empathy"; "I keep close contacts with } \\
\text { the school psychologist"; "I received } \\
\text { moral support from colleagues", "I talk } \\
\text { with administration" }\end{array}$ & 9 & 12 \\
\hline & $\begin{array}{l}\text { Use of therapy } \\
\text { or supervision }\end{array}$ & $\begin{array}{l}\text { "I have supervisions"; "Supervision } \\
\text { with the psychologist was very useful"; } \\
\text { "self-analysis"; "art and music } \\
\text { therapy" }\end{array}$ & 5 & - \\
\hline $\begin{array}{l}\text { Emotional } \\
\text { release }\end{array}$ & $\begin{array}{l}\text { Emotional } \\
\text { releases and } \\
\text { rest }\end{array}$ & $\begin{array}{l}\text { "I weep myself out, I unburden myself"; } \\
\text { "sometimes, just sleep and rest", "I } \\
\text { rested, recovered" }\end{array}$ & 4 & 4 \\
\hline
\end{tabular}


Data obtained employing the qualitative semi-structured interview, the analysis of social educators' subjective experiences enable us to look at ways, strategies of occupational stress experienced by these professionals in a complex manner and reconstruct them. Semantic units decoded and generalised in the course of the study presuppose the most characteristic contexts of stress coping strategies of these professionals in their professional activities: dissociation from a stressful situation, solution of problems, social support and emotional release.

Research data enable to state that social educators try to cope with stress in their professional activities constructively, by focusing on the problem (solution of the problem $\mathrm{N}=79$ ), and unconstructively, emotionally (dissociation from the stressful situation $\mathrm{N}=101)$, looking for social support $(\mathrm{N}=26)$, although the latter way of coping with stress can be attributed to partly constructive ways (Bulotaitė \& Lepeškienè, 2006; Pikūnas \& Palujanskienė, 2005; Kriukova, 2010; Lazarus \& Folkman, 1984).

Reconstructing the constructive space of coping with stress; i.e., solution of problems, several subcategories show up: discussion of the situation with the staff, professional development, development of the positive attitude, distinguishing priorities at work, discussion of circumstances of the situation with the pupil and family.

Research data demonstrate that seeking to cope with stressful situations in professional activities constructively, social educators discuss the problems with the staff $(\mathrm{N}=27)$, they discuss with colleagues, find new ways of solutions, organize self-help groups, where they discuss complex cases, possible solutions, share feelings and experiences. Complex situations are discussed with learners pupils and their families $(\mathrm{N}=10)$. In some cases informants rely on themselves $(\mathrm{N}=5)$, and try to cope with stress themselves (I try to solve problems myself).

Professional development $(\mathrm{N}=20)$, development of the positive attitude $(\mathrm{N}$ $=11$ ), foreseeing the priorities in professional activities $(\mathrm{N}=6)$ are also to be treated as constructive strategies oriented to the solution of the problem. Social educators read literature, seek assistance from other institutions and professionals, plan and prioritize their works, look at the situations positively, try to enjoy things.

The research data analysis shows that social educators also try to cope with stress in their professional activities in an unconstructive way, dissociating from stressful situations, trying to relax $(\mathrm{N}=21)$, engage in leisure activities $(\mathrm{N}=27)$, sport $(\mathrm{N}=19)$, separating the professional relationships from personal relationships $(\mathrm{N}=16)$, controlling and diverting emotions $(\mathrm{N}=12)$ or just emotionally releasing $(\mathrm{N}=8)$. Social educators state that in such cases they try to walk in the fresh air, nature, work physically, exercise, read books, watch comedies, listen to music, do handicrafts, not to work at the weekends or just at times weeping themselves out, unburdening themselves, sleeping off, etc. 
Trying to cope with stress, informants seek social support $(\mathrm{N}=26)$, which can also be considered to be a partly constructive stress coping strategy. This does not disclose the reason of the problem and does not solve a difficult situation but enables to control emotions, analyze oneself, get support and change the approach to the situation (Bubeliene \& Merkys 2012; Klizas \& Šulnienè 2012; Loikienė \& Pileckaitè-Markovienè 2013). Social educators receive colleagues' support ( $\mathrm{N}=$ $21)$, use therapies and supervisions $(\mathrm{N}=4)$, they state that they maintain close relationships with a psychologist, receive moral support and empathy from the administration and that colleagues, supervision, self-analysis, art and music therapy are useful for them, etc.

The differences in the responses of Lithuanian and Latvian respondents shall be examinedusing other methods, which reveal deeper stress management aspects. There is a lot of information about the stress management and it is of different quality. The respondent in his life applies what he have read and understood. From this aspect, Latvian respondents tend to apply emotion-focused coping strategy- relaxation techniques, self-control, distancing from the situation in order to change the intensity of distress.

\section{Conclusions}

In many cases, when carrying out social work in order to help the client in his life situation, the social worker faces with complications in client's situation resolution, there are no desirable results for a long time, the client often gives up because of difficulties. It causes stress for both the social worker and the client.

There is a wide range of stress coping strategies. Overcoming comprises cognitive, emotional and behavioural strategies. R. Lazarus and S. Folkman set two types of stress management: problem-oriented stress management, progress focused on the resolution of stress situation and emotion-oriented management.

This research allows to reveal coping with the professional stress strategies of social pedagogues, to notice the manifestation of productive strategies and tendencies of strategies' usage. Some differences among revealed strategies from Lithuanian and Latvian cultural context could be based on peculiarities of research methodology and different social cultural and educational contexts.

Reconstruction of the context of social educators' professional activities enabled to distinguish stress coping strategies used by these professionals, which could be conditionally divided into constructive, oriented to problem solving and unconstructive, oriented to the emotional space. Constructive, problem-solving strategies enable to look for and disclosereasons of complicated situations, their manifestation, discuss this with the participants of the situation, look for best possible solutions, improve in the professional space and mature as a personality. Analysis of empirical data revealed that Lithuanian and Latvian social 
pedagogues are using more constructive coping with professional stress strategies: to discuss the difficult problems with colleagues and parents; professional growth; ability to make priorities.

The summary of semantic units given by professionals highlights that informants also try to cope with stress in their professional activities in an unconstructive way, often emotionally or involving benefits of social context. Such stress coping strategies used by professionals do not help to disclose the reasons of stressful situations, aggravate search for most optimal solutions but enable to slightly distance themselves from stressful situations and control emotions. The analysis of data also revealed that specialists in Lithuania and Latvia are tend to go in for sports, involving into physical and more relaxing activities, or just trying to have a rest with the purpose to cope with the stress. Also those mentioned coping strategies orientated into social context are strengthened with the ability to manage their own emotions or even with the avoidance of stressful situation.

The choice of behaviour in stressful situations is a manifold complex process, which often depends on the type of the situation, its complexity, human values, psychological resistance, defence mechanisms, maturity of the personality and other variables.

This work was supported by V-A Latvia - Lithuania Programme 2014-2020 in frame of the Project "Developing of Social Psychological Support Service System through Implementation of Method of Positive Coping Strategies and Enhancement of Social Inclusion for People in Vulnerable Groups, POZCOPING, Nr. LLI-163"

\section{References}

Bartlett, D. (1998). Stress, Perspectives and process. Health psychology. Series. Chapter 1. Stress and health. Buckingham, P. 1-21

Bubelienè, D., \& Merkys, G. (2009). Bandymas žvelgti ị pedagogų profesinị stresą kompleksiškai: empirinio tyrimo duomenys. Mokytoju ugdymas, 14 (1), 88-102.

Bubelienè, D., \& Merkys, G. (2012). Pedagogų streso socialinis konstravimas ir jo atspindžiai profesineje spaudoje. Acta Paedagogica Vilnensia, 29, 100-110.

Bulotaite, L., \& Lepeškienè, V. (2006). Mokytojų stresas ir jo įveikimo strategijos.

Pedagogika, $84,48-51$.

Corbin, J., \& Strauss, A. (2014). Basics of Qualitative Research: Techniques or Developing Grounded Theory. SAGE Publishing.

Coyne, J. C., \& Lazarus, R. S. (1980). Cognitive Style, Stress Perception and Coping. In Kutach J. L., Scxhesinger L .B. Handbook on Stress and Anxiety, San Francisko, p. 144-158

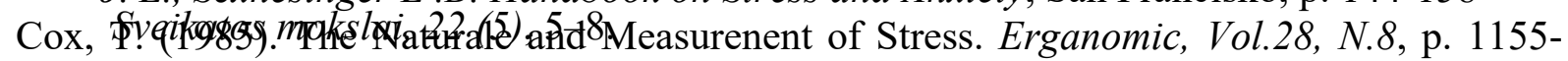
1163.

Folkman, S., \& Moskowitz, J. T. (2004). Coping: Pitfalls and promise. Annual Review of Psychology, 55, 745-774.

Frydenberg, E., \& Lewis, R. (1993). Adolescent Coping Scale: Manual. Melbourne: AC6 press.

Kepalaite, A. (2013). Socialiniu pedagogų stresas ir jo įveikos sąsajos. Ugdymo psichologija, $24,27-34$ 
Rita Orska, Daiva Alifanovienè, Odeta Šapelytè. Lithuanian and Latvian Social Educators' Occupational Stress and the Analysis of its Coping Possibilities: Social Educators'

Experiences

Lazarus, R. S. (1991). Emotion and Adaptation. New York: Springer Publisher Company, Inc., 1991.576 p. 53.

Lazarus, R. S., \& Folkman, S. (1984). Stress, appraisal and coping. New York: Springer Publisher Company, Inc., 223 p.

Loikienė, O., \& Pileckaitė-Markovienė, M. (2013). Aukštųjų mokyklų dèstytojų ir bendrojo ugdymo mokyklų mokytojų darbe patiriamo streso ịveikos stiliai. Pedagogika, 109, $78-85$.

Maslach, C. (1982). Bourout. The Cost of Caring, New Jersy

Miķelsone, B. (2011). Pētījums „Profesionālā stresa cēloṇi un situativas trauksmes lìmeña īpatnības sociālajiem darbiniekiem un Nevalstisko organizāciju darbiniekiem" sadarbibasabc.lv/wp.../B.Mikelsone_PetijumsNVO_RSD.ppt

Pikūnas, J., \& Palujanskienè, A. (2005). Stresas: atpažinimas ir ịvertinimas. Kaunas: pasaulio lietuvių centras.

Selje, H. (2011). Manas dzīves stress. Rīga: Jumava

Valickas, G., Grakauskas, Ž., \& Želvienè, P. (2010). Patobulinto keturių faktorių streso ịveikos klausimyno psichometriniai rodikliai. Psichologija, 41, 96-110.

Vazne, Ž. (2009) Spēètēaju psihiskā noturība un komandas saliedētība 16-20 gadu veciem basketbolistiem. Promocijas darbs. Rīga.

Крюкова, Т. Л. (2010). Методы изучения совладающего поведения: три копинг-шкальл. Кострома. 